\title{
РАЗВИТИЕ БИЗНЕСА В УНИВЕРСИТЕТСКОЙ СРЕДЕ
}

\section{BUSINESS DEVELOPMENT IN THE UNIVERSITY ENVIRONMENT \\ D. Grigorenko}

Summary: The stage of development of entrepreneurship institutions is a topic of growing interest from both domestic economists and foreign representatives. For Russia, the development of an innovative economic system will entail the subsequent development of innovative enterprises and public-private partnerships, which will significantly change the position of our country at the macroeconomic level.

A prerequisite for the formation of an innovative economy is the modernization of the education system, accompanied by dynamic economicgrowth and social development of the information environment. Education is one of the most important factors in the formation of the information society, since the prospects for the progressive development of mankind depend to a large extent on its orientation and effectiveness. The education system today is experiencing significant pressure from the market. The ratio of state and non-state financing has changed. Budgeting for secondary and higher educational institutions is reduced annually. HPE and HE institutions are forced to diversify their sources of funding by more actively attracting sponsors, introducing or increasing tuition fees, as well as receiving funds from their own entrepreneurial activities and other types of economic activity.

Such a state policy "forces universities to search for ways to attract extrabudgetary funds that are both specialized, educational in nature and non-core commercial".

The article describes in detail ways to support entrepreneurship in the educational sector. Examples of their application in practice are given.

Keywords: entrepreneurship, university, business incubator, business project, innovation.

Григоренко Дарья Константиновна Аспирант, Среднерусский институт управления - филиал РАНХИГС, Орел ostroukhova1995@mail.ru

Аннотация: Стадия развития институтов предпринимательства - тема, вызывающая все больший интерес со стороны, как отечественных экономистов, так и зарубежных представителей. Для России развитие инновационной экономической системы повлечет за собой последующее развитие инновационных предприятий и государственно-частных партнерств, что существенно изменит положение нашей страны на макроэкономическом уровне.

Необходимым условием для формирования инновационной экономики является модернизация системы образования, сопровождающаяся динамичным экономическим ростом и социальным развитием информационной среды. Образование является одним из важнейших факторов формирования информационного общества, поскольку от его направленности и эффективности в значительной степени зависят перспективы прогрессивного развития человечества.

Система образования сегодня испытывает значительное давление со стороны рынка. Изменилось соотношение государственного и негосударственного финансирования. Бюджетирование средних и высших учебные заведения ежегодно сокращается. Учреждения ВПО и ВО вынуждены диверсифицировать источники финансирования за счет более активного привлечения спонсоров, введения или увеличения платы за обучение, а также получения средств за счет собственной предпринимательской деятельности и других видов хозяйственной активности.

Такая государственная политика «заставляет университеты заниматься поиском путей привлечения внебюджетных средств, носящих как профильный, образовательный характер, так и непрофильный - коммерческий».

В статье подробно описаны способы поддержки предпринимательства в образовательной сфере. Приведены примеры их применения на практике.

Ключевые слова: предпринимательство, университет, бизнес-инкубатор, бизнес-проект, инновации.

дельных ее областях.

Вопросы развития преАпринимательской Аеятельности на территории Российской Фецерашии $\Delta$ н настояшего времени продолжают оставаться актуальными.

Малое предпринимательство является движущей силой роста деловой активности в большинстве стран мира. Оно порождает здоровую конкуренцию, насыщает рынок новыми товарами и услугами, обеспечивает занятость и самозанятость населения. Последнее в России и в большинстве регионов страны так и не реализовано, в виду того, что структура малого предпринимательства имеет существенные недоработки. Отсутствие четкой системы деловых отношений, несвоевременное предоставление информации об изменениях в регламентирующих документах, регулярное повышение ставок налогообложения - эти и многие другие барьеры сдерживают развитие предпринимательства в России в целом и от-
«Малый и средний бизнес развивается на территории Российской Федерации неравномерно» (рис. 1). Сектор малого предпринимательства сосредоточен в сферах торговли и услуг.

Средние предприятия преобладают в сферах с более высокой добавленной стоимостью [15]. Как правило, это сельское хозяйство, строительство, обрабатывающая промышленность.

Согласно данным Федеральной службы государственной статистики РФ, доля занятого населения В малом бизнесе на 2018 г. составила 24,9\% [6]. Для сравнения: доля малого и среднего бизнеса в ВВП развитых стран составляет 50-60\%. Так, в Великобритании это $51 \%$, в Германии - 53\%, в Финляндии - 60\%, в Нидерлан- 


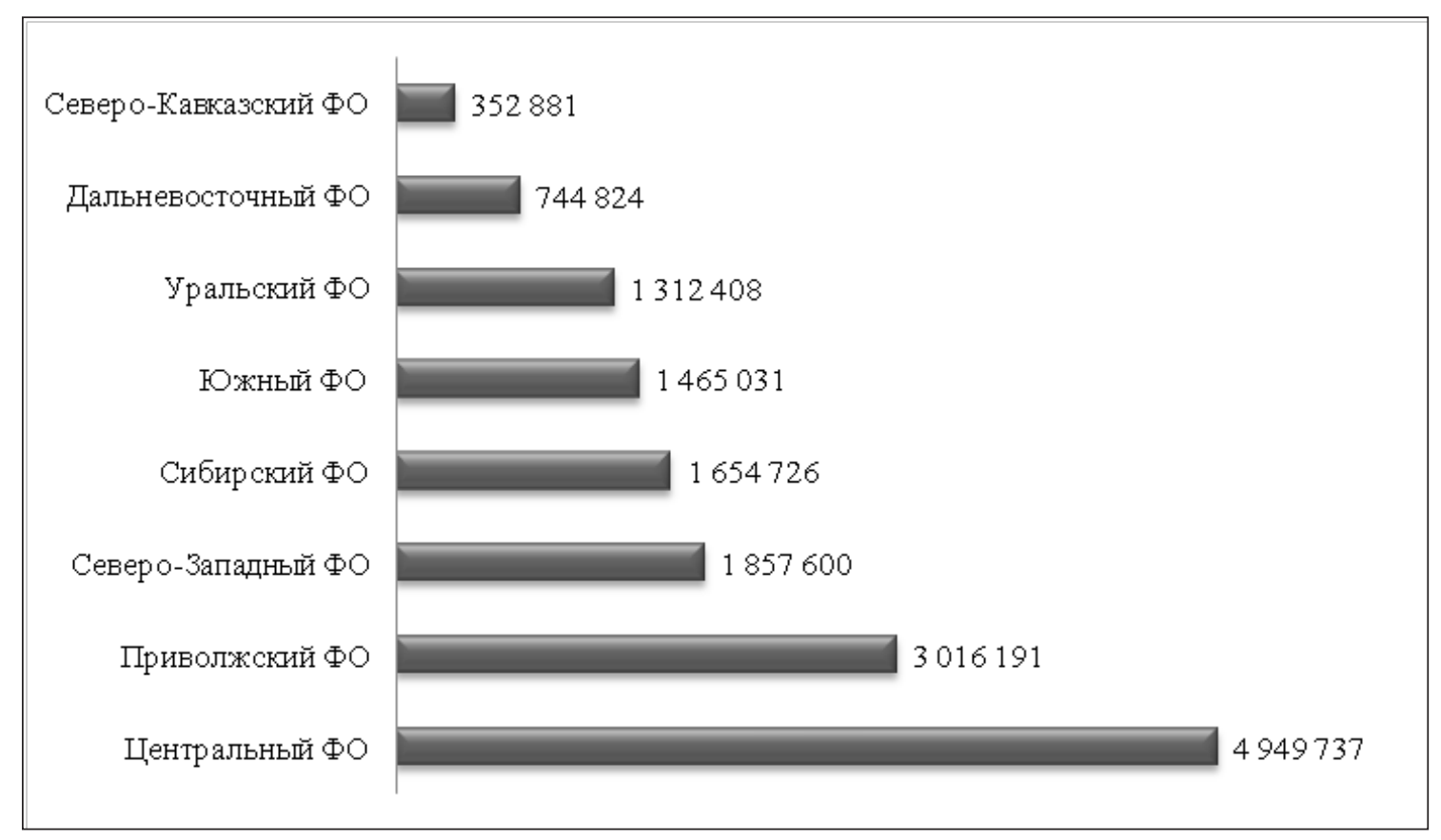

Рис. 1. Количество работников, занятых в сфере предпринимательства в 2018 г.

дах $-63 \%[10]$.

Россия намерена сократить такое отставание от стран Евросоюза. По плану Стратегии 2030 «Развитие малого и среднего предпринимательства в Российской Федерации», к 2030 году доля МСП России в валовом внутреннем продукте должна возрасти вдвое, и составить 50\% [15].

Достичь подобных значений показателей - задача «амбициозная», но в будущем вполне достижимая. Однако ее реализация будет невозможна без налаженной тесной взаимосвязи со сферой науки, формирующей и стимулирующей рост «креативного класса» - людей творческого труда, создающих инновации в ходе своей обычной работы.

Как и малый бизнес, инновационный потенциал является ключевой составляющей современной экономической системы.

О значимости инноваций в сфере предпринимательства неоднократно упоминает в своих научных исследованиях С.А. Коробов - доктор экономических наук, доцент кафедры менеджмента Волгоградского государственного университета.

«Инновация есть процесс коммерциализации идеи, достижение успеха благодаря производству полезного продукта, процесса или блага, то есть изобретение становится нововведением, если достигает успеха на рынке. На основании этого важнейшими свойствами ин- новации являются: научно-техническая новизна; практическая применимость (использование нового продукта в различных отраслях экономики); коммерческая реализуемость (нововведение реализуется на рынке, то есть оно способно удовлетворить потребности клиентов)» [Марусинина и др., 2019, с. 102-113].

Автор замечает «что сегодня не происходит того прорыва, который прогнозировали в среде промышленного применения наукоемких разработок, изобретений, технологий и т.п., поэтому и не следует ожидать в отечественной экономике бесперебойного процесса реализации наукоемкой продукции на рынке. Одним из характерных итогов подобных тенденций можно рассматривать, например, отсутствие положительной динамики с 2010 по 2016 годы по численности крупных и средних предприятий, осуществлявших инновационную деятельность. Все это в целом обуславливает актуальность любых исследований, рассматривающих проблематику развития инновационной среды» [Коробов и др., 2019, с. 59-63].

«В этой связи ценной рекомендацией может стать создание крепких связей между корпорациями и научно-исследовательскими центрами на базе ведущих университетов. Такой опыт успешно применялся еще в советское время. Крупные компании могут создавать небольшие дочерние компании, нацеленные на новые разработки или реализацию локальных бизнес-задач» [19].

Современные высшие учебные заведения не только продолжают играть ключевую роль в формировании 
основ научного знания (проводят исследования, внедряют и распространяют полученные в ходе экспериментов результаты), они воспроизводят человеческий капитал, необходимый для «инновационного развития общества». Расширился и перечень выполняемых ими функций. Теперь, помимо «реализации образовательных программ, подготовки, переподготовки и повышения квалификации своих сотрудников, организации и проведении фундаментальных, поисковых и прикладных научно-исследовательских работ» и других видов основных функций, университеты стали обязаны исполнять и другую немаловажную работу, а именно: «развитие практико-ориентированных исследований, а также создание и внедрение новых технологий».

Меняется и направление вектора миссии университетов. Кроме образования и производства новых научных знаний, отдельно выделяют «идею включенности университета в решение значимых для общества проблем».

Исследования о так называемой «третьей миссии» университетов вызывают у оппонентов массовую заинтересованность. Балмасова Т.А. - аспирантка Новосибирского государственный технический университета, в своей статье «Третья миссия» университета - новый вектор развития?» [Балмасова, 2016, с. 48-52] акцентирует внимание на следующих концепциях миссии университета: «продолженное обучение», «социальное участие» и «трансфер технологий и инноваций».

Первая упоминается автором как обучение на протяжении всей жизни. «Она направлена на повышение качества знаний, навыков и компетенций, гарантирующие личную, перспективную, гражданскую социальную занятость». Вторая - это «тесное сотрудничество знаний, полученных в стенах учебного учреждения, и ресурсов общественно-частного сектора». Такое «партнерство» модернизирует процесс образования, расширяет область исследований, увеличивает креативность, и совершенствует учебные планы учреждения, чем способствует укреплению гражданской ответственности и поддерживает блага общества [Балмасова, 2016, с. 4852].

О третьей концепции Балмасова Т.А. пишет следующее: «Измерение трансфера технологий и инноваций может быть определено как продвижение идей, практик, ноу-хау, технического знания, интеллектуальной собственности, открытий или изобретений, получаемых в результате исследований, проводимых в университете, во вне академического окружения, что приводит к социальной и коммерческой пользе на местном, региональном, национальном или глобальном уровнях».

Исходя из представленных выше тезисов и рассужде- ний, является неоспоримым тот факт, что так называемая «третья миссия» обеспечивает учреждения ВПО и ВО прочными взаимоотношениями между университетами и коммерческими организациями, что, в свою очередь создает необходимые условия для их трансформации и переход от традиционной формы функционирования к предпринимательской.

Согласно мнению британского ученого Дж. Ропке: «предпринимательский университет должен демонстрировать предпринимательское поведение как организация; члены университета - преподаватели, студенты, сотрудники - должны быть предпринимателями; взаимодействие между университетом и окружающей средой должно приводить к взаимодействию университета и региона в части развития бизнеса» [Буняк, 2016, с. 144-147].

Развитие бизнеса в университетах России пока находится на начальном этапе. Это связано с тщательно выстраиваемым процессом учебно-научного взаимодействия студенческих бизнес-клубов и бизнес-проектов, спецкурсов, факультативов, и др. программ, направленных на всевозможную помощь и поддержку студенческих бизнес-начинаний. (рис.2). Он выявляет и развивает у абитуриентов предпринимательские способности и повышает их заинтересованность к коммерческой активности.

Тактика процесса определяется как тенденция накопления ресурсов для использования и продвижения предпринимательских кампаний, созданных в стенах ВУЗа отдельными студентами и научными сотрудниками, или целыми подразделениями и лабораториями, в результате, которой происходит трансформация классического университета в предпринимательский [18].

Одним из современных способов, направленных на «взращивание» и развитие коммерческих организаций, являются бизнес-инкубаторы.

«Бизнес-инкубаторы - это специализированные институты рыночной инфраструктуры, созданные в целях поддержки малых предприятий путем создания максимально благоприятных («тепличных») условий для их развития в течение определенного периода - «инкубирования»». Они ускоряют развитие малых предприятий в 7-22 раза, снижая количество неудач в бизнесе до $20 \%$ [Алексина, 2014, с. 16-26].

Истории создания бизнес-инкубаторов многообразны. Каждый из них имеет свою особенную, специфическую цель существования.

В Соединенных Штатах Америки интерес к инкубаторам возник только в 1980-х годах после того, как приток 


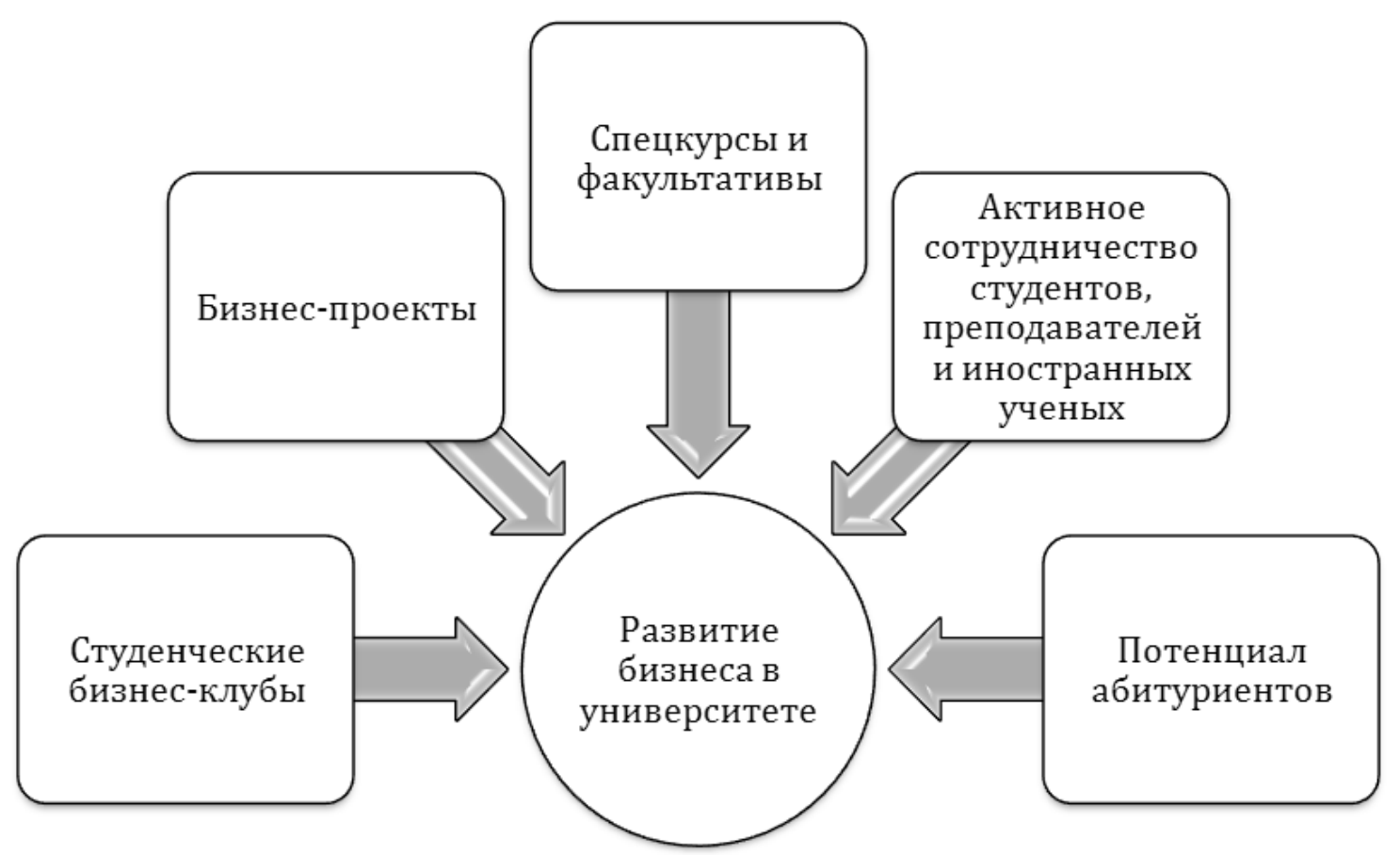

Рис. 2. Составляющие стратегии «Выращивания» бизнеса в университетах России.

высших учебных заведений решил запустить школьные бизнес-инкубаторы, чтобы предложить учащимся лучшие перспективы трудоустройства.

Большинство ведущих американских инкубаторов являются отраслевыми. Например, the Houston Technology Center специализируется на поддержке энергетических компаний, the Massachusetts Biomedical Initiatives сосредоточены на биотехнологии, а инкубатор в Чикаго - на технологических компаниях. Кроме того, в отдельную группу выделяют такие инкубаторы как The Research Park в Университете Иллинойса и Инновационный центр MGE в Мэдисоне, штат Висконсин. И тот и другой признаны ведущими инкубаторами Америки, поскольку делают акцент на предоставлении услуг арендаторам, а не продукции.

В странах Азии большинство бизнес-инкубаторов создается с целью поддержки предпринимательства среди студентов и выпускников университетов, что прослеживается в политике отбора проектов. «Указанный мотив сопровождает стремление властей с помощью взаимодействия «государство - университет - частный сектор» стимулировать развитие инновационных отраслей экономики. Например, при Университете Осаки (Япония) основной целью создания инкубатора является поддержка малых и средних предприятий, занимающихся исследованиями и разработками в сфере биотехнологий».

В европейском регионе тенденция такова: «все инку- баторы располагаются на базе крупнейших европейских университетов, входящих в топ-200 мировых рейтингов. В частности, Технического университет Чармельса признан лучшим в Швеции и является одним из крупнейших исследовательских центров Европы. Несмотря на то, что университет носит название «технический», в нем реализуются программы разных профилей» [7].

Инкубаторы создаются и на базе университетов, осуществляющих подготовку специалистов по одному направлению. «Примером в данном случае, является Высшая школа коммерции Парижа (бизнес-инкубатор при университете - Incubateur), готовящая специалистов в области менеджмента. Высшая школа коммерции является старейшей бизнес-школой в мире» [Артемова,2016, c. 75-86].

Весомый вклад в изучение такого способа поддержки предпринимательства вложили работы и исследования зарубежных и отечественных специалистов, отмечающих особую значимость университетов в современном мире. Университеты сегодня - это центры управления знаниями, способствующие распространению технологических инноваций и экономическому развитию региона.

В своей работе «Эффективность функционирования бизнес-инкубаторов как элемента спин-офф стратегии университетов» Рогова Е.М. - доктор экономических наук, профессор, заведующая кафедрой финансовых рынков и финансового менеджмента Санкт-Петербургского фи- 
Мониторинг и отбор клиентской базы

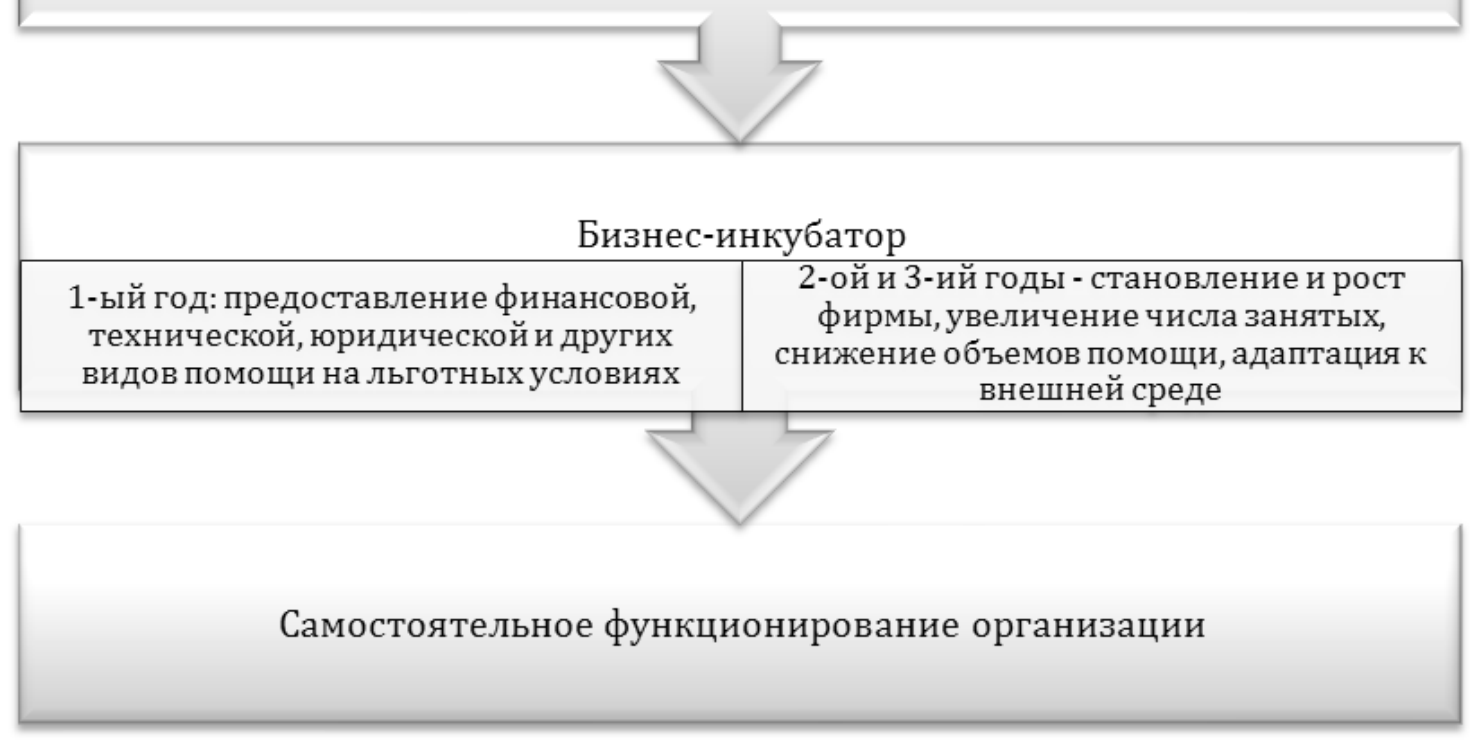

Рис. 3. Схема функционирования бизнес-инкубатора.

лиала Национального исследовательского университета «Высшая школа экономики» пишет: «Принято считать, что бизнес-инкубаторы создаются для «Выращивания» новых фирм и, при этом, они исключают процесс «создания» (рис.3). Несмотря на тот факт, что форма создания организации, как и форма «выращивания» фирмы имеют общие характеристики (например, оба процесса формируются различными учредителями на коммерческой основе) есть одно важное отличие. Когда речь идет об инновационных стартапах - все меняется. Ключевым учредителем бизнес-инкубатора является университет, роль бизнес-инкубаторов сводится к содействию формирования компаний спин-офф, коммерциализирующих результаты интеллектуальной деятельности своих сотрудников, организационно-правовая форма бизнес инкубатора - это некоммерческое партнерство. Такой подход функционирования характерен для большинства бизнес-инкубаторов в России».

В зависимости от уровня развития предпринимательских способностей основоположников компаний спин - офф, оценки экономического окружения, а также сложившихся между предпринимателями, университетом, представителями региональных органов власти и крупных предприятий региона сетевого взаимодействия, формируется успешность трансферта технологий. Такое взаимодействие будет считаться успешным, в случае, если бизнес-инкубаторы представлены в качестве площадок, где возникает тесная взаимосвязь интересов академической среды, предпринимателей и представи- телей власти.

Выходит, что бизнес-инкубатор представляет собой так называемое «ядро» разносторонних интересов участников региональной инновационной системы, субъекты инкубатора используют такой способ решения конфликтов как стейкхолдерский подход (рис. 4).

В зависимости от интересов стейкхолдеров, показатели деятельности бизнес-инкубатора (показатели развития бизнес-инкубатора, показатели развития резидентов, показатели влияния работы бизнес-инкубатора на развитие резидентов) не всегда будут одинаковы.

Каждый из показателей, может быть определен одним или несколькими числовыми значениями. «Результат - успешное функционирование организации в бизнес-инкубаторе или предприятий, которые конкретизируются в финансовом аспекте как рентабельность резидентов» (рис.5).

Рогова Е.М. также акцентирует внимание на реализации концепции реальных опционов.

Опцион - это альтернативное право вкладчиков на получение необходимой ценной информации о проекте в условиях внешней среды. Не стоит путать его с обязанностью. «Такая форма оценки бизнес-инкубатора возможна под воздействием такого ряда факторов как существование неопределенности относительно ре- 


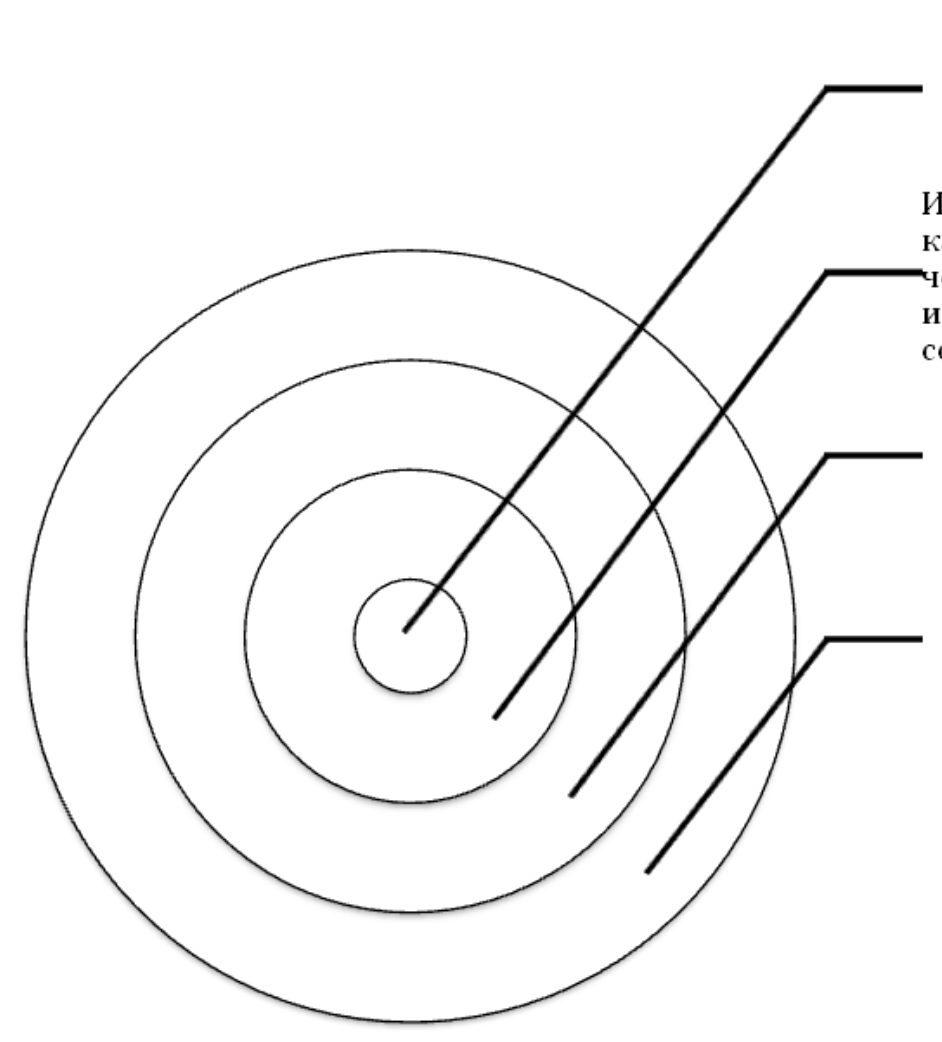

Ифраструктура транфера знаний и технологий: бизнес-инкубаторыи технопарки

Интересыуниверситетов: капитализация знаний через управление интеллектуальной собственностью

Интересыкрупньх компаний: снижение затрат и рисков на инновационную деятельность

Рис. 4. Интересы стейкхолдеров бизнес-инкубаторов [Рогова, 2014, с. 53-58].

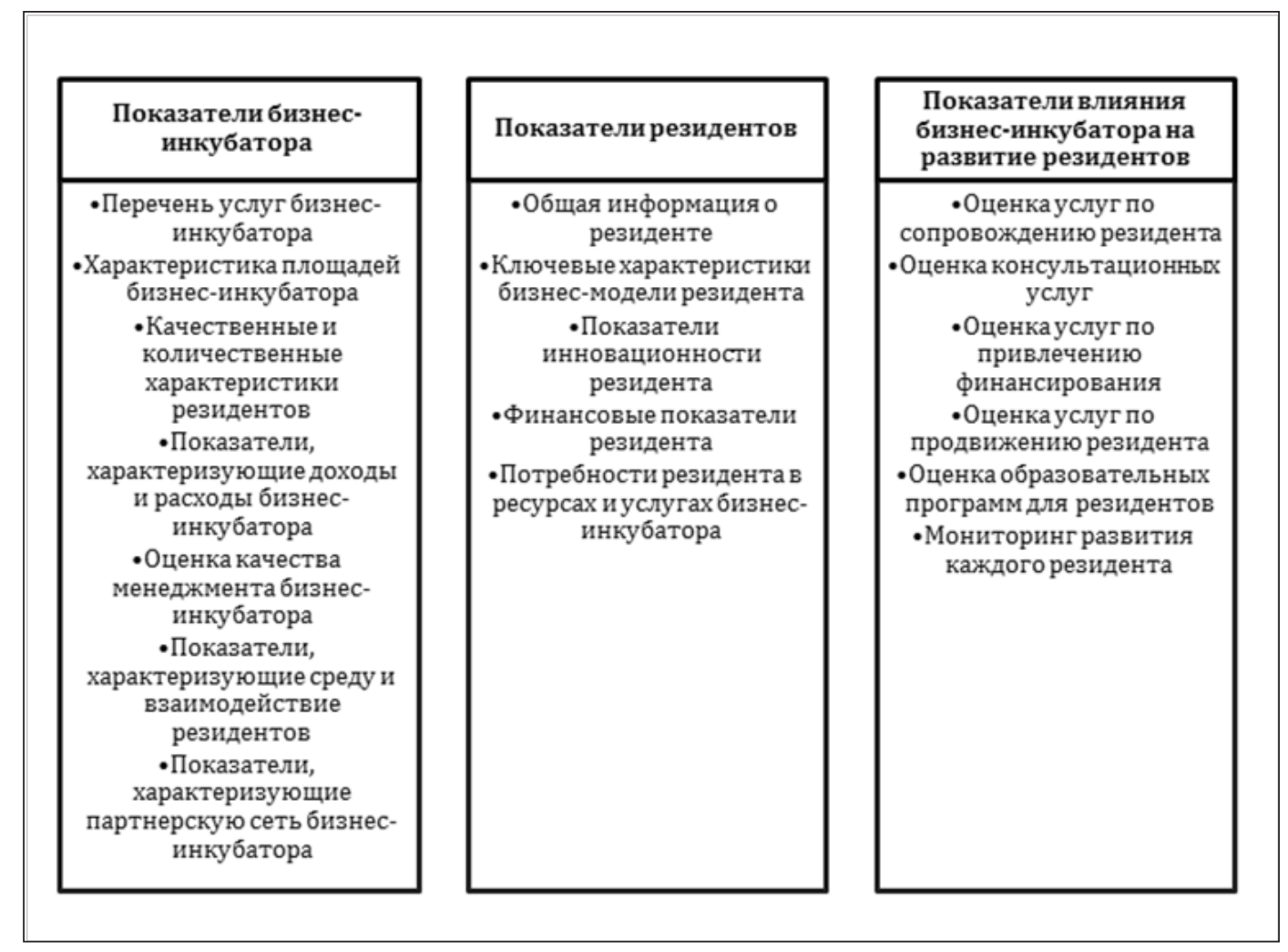

Рис. 5. Показатели «эффективности и результативности» деятельности бизнес-инкубаторов 
зультатов реализации проекта, наличие активов, необратимость инвестиционного процесса, характерная для любых реальных инвестиций, затраты на исполнение опциона, конкурентные рынки ресурсов и сбыта продукции проекта».

Рогова Е.М. пишет: «Университет, выступающий как инвестор для инкубатора, с точки зрения реальных опционов, рассматривает подобную форму поддержки бизнеса как «инвестиционный проект с опционом на расширение или осуществление последовательных инвестиций». Спин-офф компания - это представитель бизнес-инкубатора, вкладывающий знания и технологии, формирующиеся в учреждении, и порождающий реальный опцион. Его поддержка рассматривается в качестве содействия в привлечении инвестиций, оказания технической помощи, консультирования, разработки образовательных программ и мониторинга»

Автор выделяет возможные результаты малых инвестиционных предприятий, образованных на базе бизнес-инкубаторов. К наиболее распространённым относят: интенсивный рост фирмы; «рост фирмы в соответствии с темпами роста рынка и увеличение рентабельности; предприятие балансирует на точке безубыточности; фирма, минимизируя свои финансовые поддержки, прекращает свое функционирование еще в период нахождения в инкубаторе; фирма прекращает свое существование еще на базе инкубатора без значительных финансовых потерь».

Для отечественной экономики развитие бизнес-инкубирования, как способ поддержки малого предпринимательства, является наиболее актуальным, в виду её специфических условий. Бизнес - инкубатор обеспечивает поддержку процесса преобразования конкретных новорожденных идей, обладает «жизнеспособным» потенциалом, обеспечивающий прибыльный бизнес. «Снижение степени рисков в период становления бизнес - инкубатора будет способствовать экономическому росту новорожденных компаний, которые не выжили бы без увеличения рабочих мест и других социальных и экономических нововведений».

В России бизнес-инкубаторы функционируют на базе экономических ВУЗов, в частности на факультетах экономически классических университетов. Из чего следует, что резидентам больше необходима помощь в составлении эффективного бизнес-плана, финансовом моделировании, инвестиционном проектировании и в решении юридических проблем, чем, собственно, в области исследований и разработок. Среди привлекаемых в бизнес-инкубаторы экспертов большинство экономисты, менеджеры, маркетологи и юристы.

Узконаправленным классом бизнес-инкубаторов яв- ляется технологический. Технологические бизнес-инкубаторы развивают информационные технологи, содействуют коммерциализации научных разработок, создают и внедряют новшества, увеличивают конкурентоспособность региональной промышленности.

Услуги, предоставляемые технологическим бизнесинкубатором различны и разнообразны. Они целиком и полностью зависят от деятельности его резидентов. Помощь в установлении связей с инвесторами, предоставление консалтинговой и информационной помощи, предоставление офисных помещений - это и многое другое не полный перечень предоставляемых технологическим бизнес-инкубатором услуг.

К технологическому бизнес-инкубатору относится созданный в 2010 году бизнес-инкубатор РАНХиГС «InCube» [4]. Он представляет собой коммуникационную некоммерческую площадку для обмена опытом, объединения результатов научно-технической деятельности студентов и слушателей РАНХиГС, предоставления научно-технологической базы начинающим предпринимателям и содействия в развитии инновационной экономики РФ.

Бизнес-инкубатор «InCube» организует сессии для привлечения потенциальных инвесторов, финансирует исследования в области экономических наук, оплачивает патенты и регистрирует юридические лица.

На площадке инкубатора было запущено более 120 стартапов. Один из самых перспективных - проект ePythia, сервис персонального планирования для смартфонов с возможностью привязать задачу к точке на карTe [14].

Помимо бизнес-инкубатора «InCube», наиболее крупными и заслуживающими внимания являются: инкубатор университета ИТСМО в Санкт-Петербурге (признан лучшим инкубатором 2017 г. за наибольшее количество успешных проектов в сфере IT и интернет-сегменте), бизнес-инкубатор ГУ-ВШЭ (отличается большим количеством программ и работает одновременно примерно с 50 проектами, 4-6 из которых впоследствии становятся выпускниками) [11].

Безусловно, бизнес-инкубаторы оказывают положительное влияние на развитие малого и среднего предпринимательства. Однако вопрос об эффективности процесса бизнесс-инкубирования пока остается спорным. Причиной тому служит недостаток общепризнанных методов оценки качества. Статистические данные, собираемые отечественными и зарубежными организациями, не позволяют создать единый подход к оценке эффективности операции. Одна из причин - отсутствие единого понимания эффективности для бизнес-инкуба- 


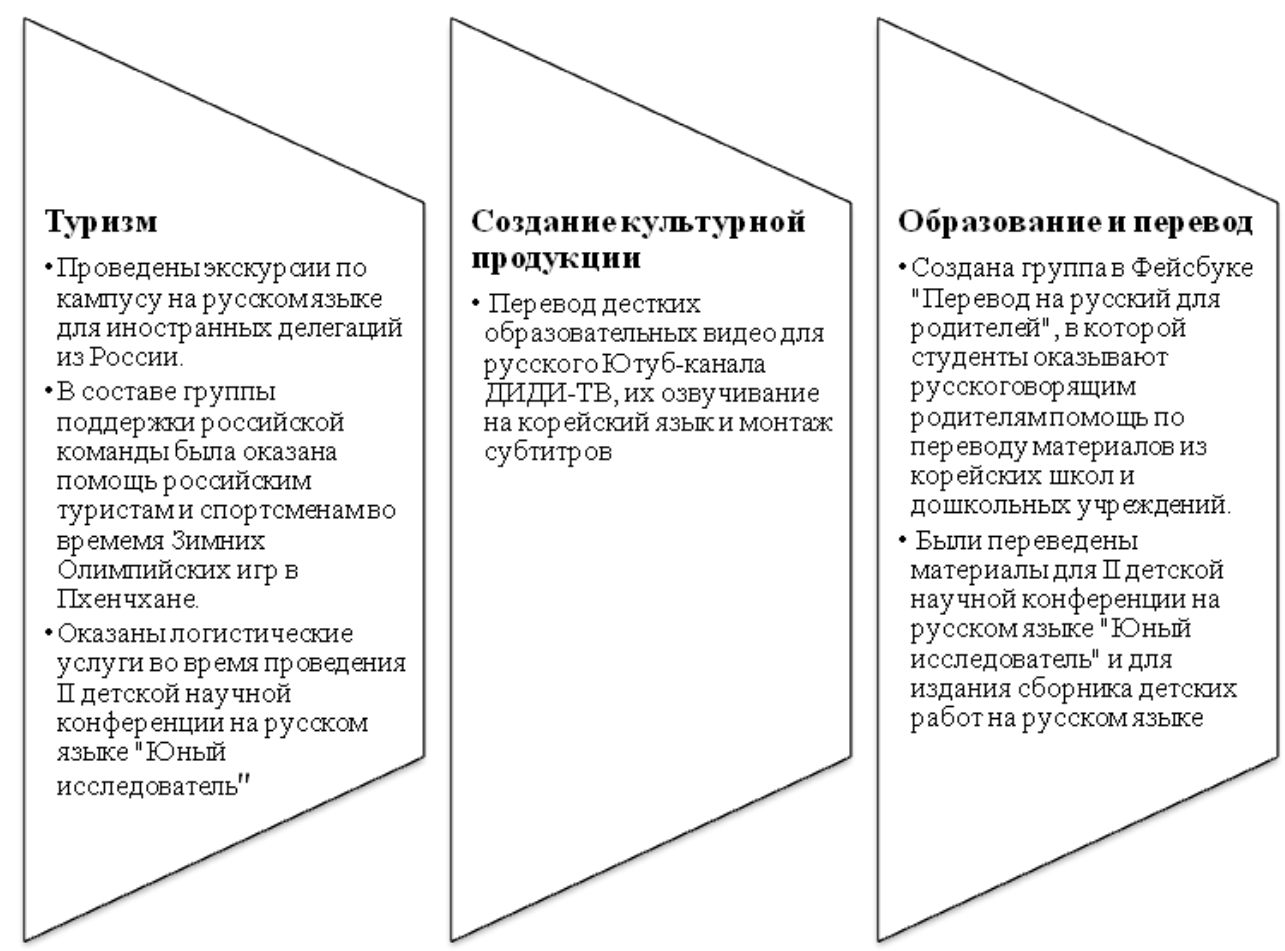

Рис. 6. Реализуемые проекты командой Южнокорейского университета Согён

торов в связи с разнообразием их видов (классический, технологический, экономический, виртуальный др.) и специфических наборов характеристик. В зависимости от типа бизнес-инкубатора цели, ключевые факторы успеха, основные показатели эффективности будут существенно отличаться между собой. Кроме того, работа над запуском того или иного вида бизнес-инкубатора задача достаточно сложная и финансово-затратная, требующая от руководства и участников инкубатора высокого уровня мотивации.

К сожалению, позволить себе быть учредителем или соучредителем бизнес-инкубирования может не каждое образовательное учреждение. Поэтому, применительно к отдельным регионам, ВУЗы прибегают к менее затратным способам реализации студенческих бизнес-идей на практике.

В связи с ограниченными возможностями запуска студенческого бизнес-инкубатора в своем муниципальном округе, филиалы РАНХиГС принимают участие в проектах предпринимательской направленности. Одним из таких является широкомасштабный образовательный проект RAISE(RanepalnspiringSocialEntrepreneurship), в котором принимают участие студенты всех филиалов РАНХиГС и многих других Российских ВУЗов. В рамках данного конкурса происходит создание и реализация студенческих бизнес-проектов, направленных на решение проблем социального характера. Решение должно быть сформировано на основе предпринимательского подхода. Это является главным критерием оценки про- екта.

Обобщим лучшие практики.

Проект команды Южнокорейского университета Согён «SURTS» (SeokyeongUniversityRussianTranslationServi се) был направлен на популяризацию русского языка в Республике Корея. Цель проекта - «развитие предпринимательства в области индустрии перевода, оказание переводческих услуг социально незащищённым слоям населения, а также достижение образовательного эффекта через вовлечение в проектную деятельность учащихся и повышение их профессиональных и языковых навыков».

Целевая аудитория - представители русскоговорящей диаспоры из России и СНГ, а также дети из мультикультурных семей, проживающие в Южной Корее [Гадиева, 2019, с. 152].

Проект был реализован в рамках программы поддержки студенческих стартапов, Центра помощи по трудоустройству и профориентации университета. Для осуществления проекта были зарегистрированы 3 бизнес-команды, каждая из которых получила финансовую помощь на реализацию проекта в размере 500 долл.

На этапе реализации проект SURTS был оформлен как университетский стартап, в рамках которого были созданы три бизнес-группы, осуществляющие проекты по каждому из направлений (рис. 6). 

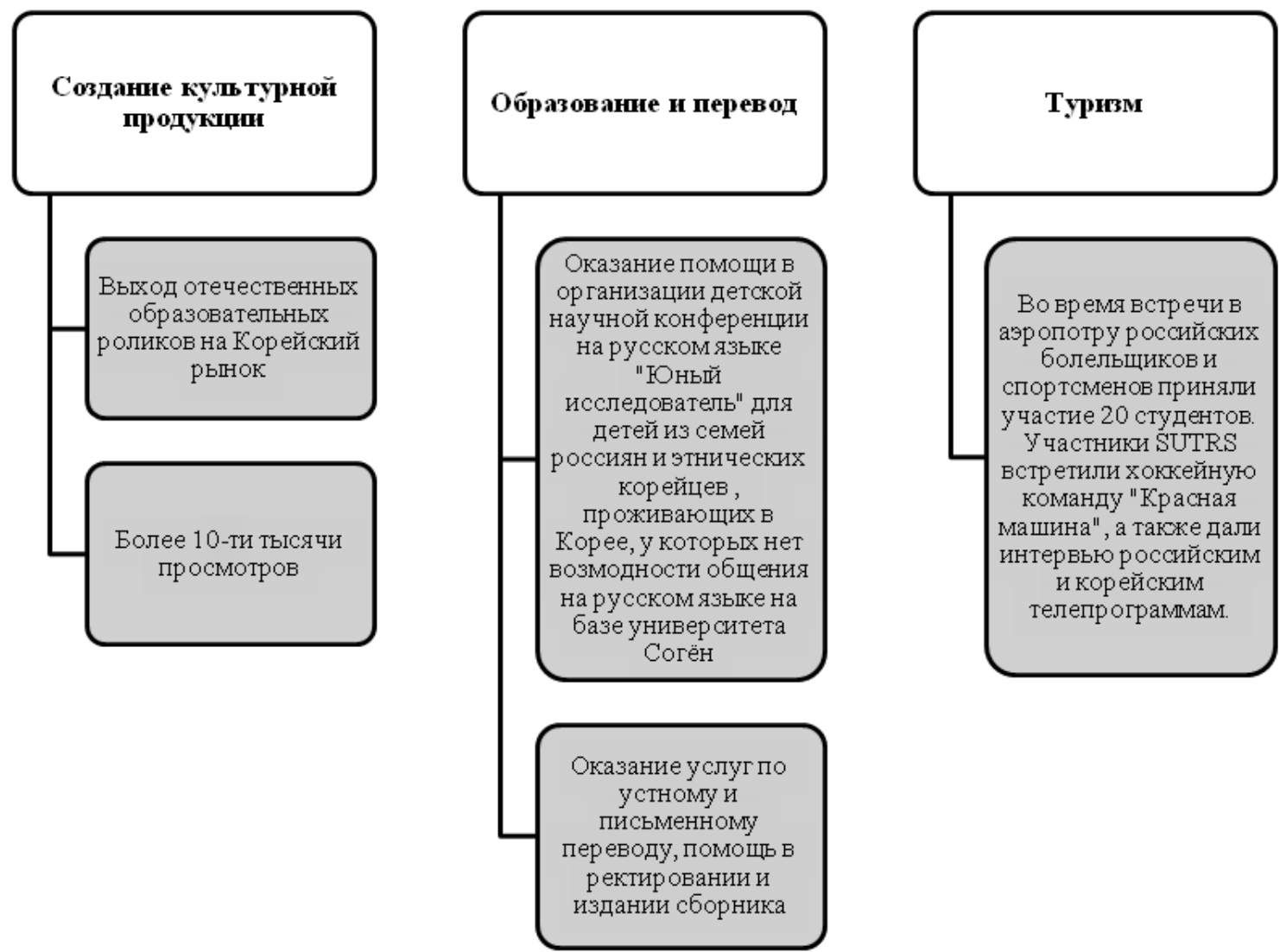

Рис. 7. Социальный эффект проекта.

Результаты реализации студенческих проектов представлены на схеме (рис.7).

Доход от продажи образовательных видео с корейским дубляжом (компания ДИДИ - ТВ), от работы по сопровождению конференции и перевода материалов сборника составил 700 долл.

Важным достижением проекта по социальному предпринимательству в области индустрии перевода SUTRS является образовательный эффект. За период осуществления проекта (2-ой учебный семестр 2017 г., 6 месяцев) было задействовано более 20 студентов университета Согён. Они получили возможность практического применения профессиональных навыков, что повысило их мотивацию к изучению русского языка и в последующем возможность трудоустройства по специальности. Группа из трех студенток (Ким Еджин, Ким Е Джи и Хан Кен A) приняла участие в конкурсе RAISE в Москве, где выступила с презентацией о проекте и университете на русском языке [Гадиева, 2019, с. 152].

Проектная команда Нижегородского института управления - филиала РАНХиГС существует на протяжении 4 лет. За это время студентами было реализовано 16 серьёзных проектов, один из которых - «Жизнь в стиле ЭКО».
Идея вторичного использования баннера имеет большую популярность на Западе, в то время как в России подобная практика почти отсутствует. Именно поэтому участники решили перенять иностранный опыт.

В первый год реализации проекта команда запустила производство сумок и аксессуаров из баннерной ткани для молодежи в возрасте от 18 до 30 лет, а также осуществляла корпоративные заказы для партнёров. В последующий год результаты проведенного опроса позволили расширить целевую аудиторию и ассортимент производимой продукции. Помог в этом выигранный грант от компании BritishPetroleum в размере 180 тысяч рублей. Среди клиентов появились как государственные, так и бизнес-организации, а также люди среднего и старшего возраста. Специально для них участники проекта разработали новые виды изделий для повседневного применения, использования на даче, а также для занятий спортом [Социально-ориентированная проектная ..., 2017].

В ходе работы проекта выпускники колледжа технологии и дизайна провели серию мастер-классов по пошиву и оформлению изделий из баннерной ткани, среди которых чехлы для музыкальных инструментов, тенты, пуфики и различные аксессуары. В итоге 7 дизайнеров 


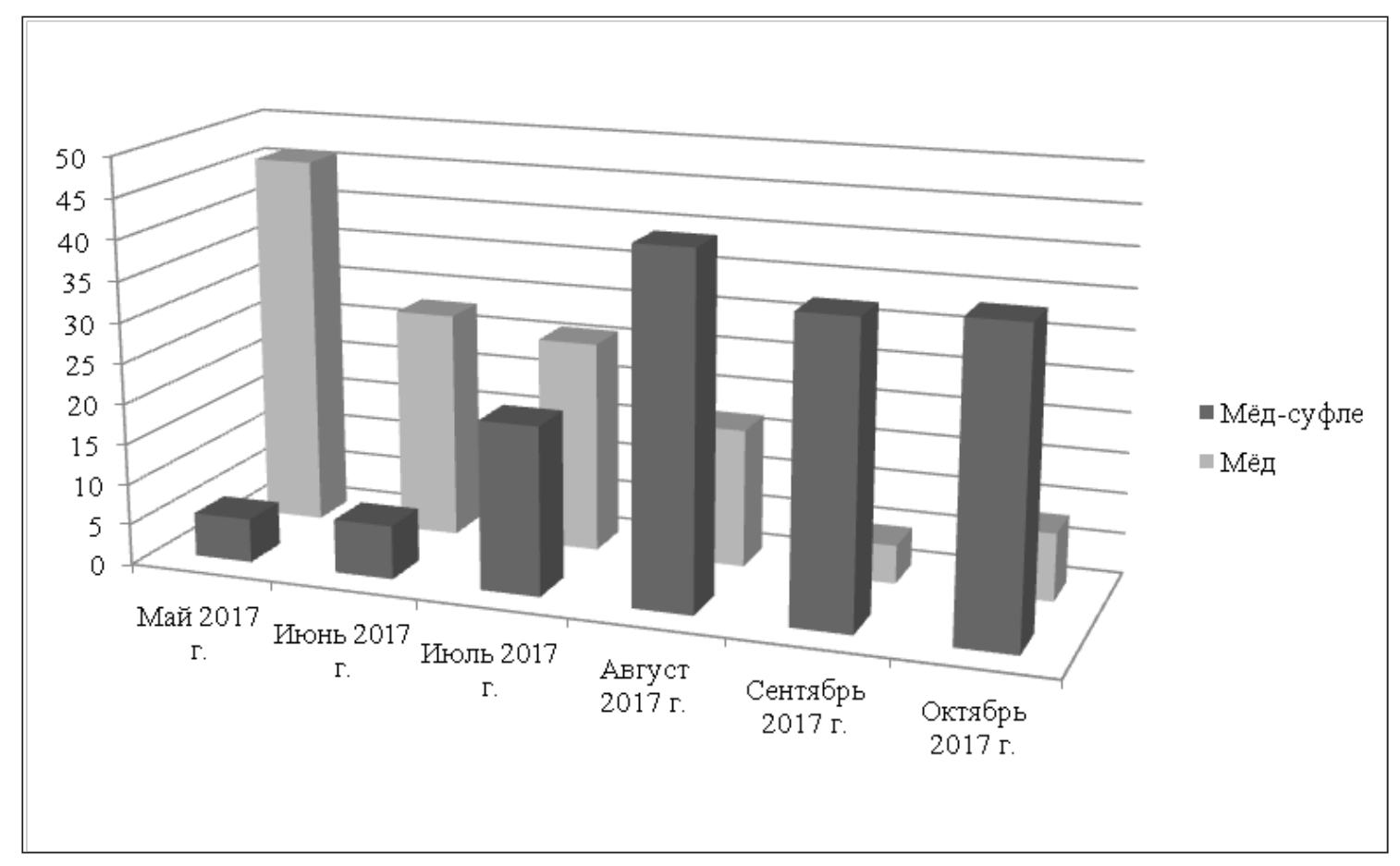

Рис. 8. Реализация продукции в 2017 году

работают над созданием собственных коллекций, а 74 человека, прошедшие тренинги, могут сами изготавливать товары. Всего было реализовано 79 изделий, переработано более 3,5 тысяч кв. м. баннерной ткани. Общее количество вырученных средств составило 60000 рублей.

Высокие показатели результативности позволяют говорить о социально-практической значимости проекта.

Бизнес-проект команды Среднерусского института управления - филиала РАНХиГС в 2018 году занял третье место в лиге. Команда Орловского филиала работала над проблемой безработицы пенсионеров деревни Морозово Орловской области.

Деятельность проекта состояла в помощи пенсионерам производить и реализовывать экологически-чистую продукт (мед-суфле). Цель работы заключалась в предоставлении возможности трудоустройства жителям деревни Морозово Покровского района Орловской области.

Задачи проекта, карта реализации продукции и результаты работы проиллюстрированы ниже на рисунках 8 - 9 и таблице 1.

Проект не утратил своей актуальности и продолжает функционировать в процессе совместной работы студентов Среднерусского института управления - филиала РАНХиГС и жителей деревни Морозово.
Для успешной реализации студенческих проектов рекомендуется добавить дополнительные этапы инкубирования бизнес - проекта и объединить их под названием инкубатор проектов.

Инкубатор проектов, как элемент бизнес-инкубатора - это образовательный тренажер для студентов, желающих овладеть компетенциями по управлению проектами на высоком профессиональном уровне. Его сущность заключена в содействии подготовки и проработки проектов студентов, аспирантов, молодых ученых и защиту этих проектов на базе организаций - партнеров университетов, а также консультировании студентов и абитуриентов основам бизнеса. Под миссией инкубатора проектов подразумевают формирование предпринимательской среды, способствующей созданию новых конкурентоспособных предприятий, профессиональному развитию студентов и аспирантов.

Обучение основам бизнес-проектирования на базе инкубатора проектов является практикоориентированным. Обычному выпускнику ВУЗа после устройства на работу потребуется время, чтобы адаптироваться и наработать практику. Студентам, прошедшим обучение на базе инкубатора проектов, этого не понадобиться. На современном рынке труда востребованы многопрофильные профессионалы, и студенты-участники инкубатора проектов соответствуют данным требованиям.

В инкубаторе проектов студенты получают углублённые знания по управлению проектами, маркетингу, биз- 


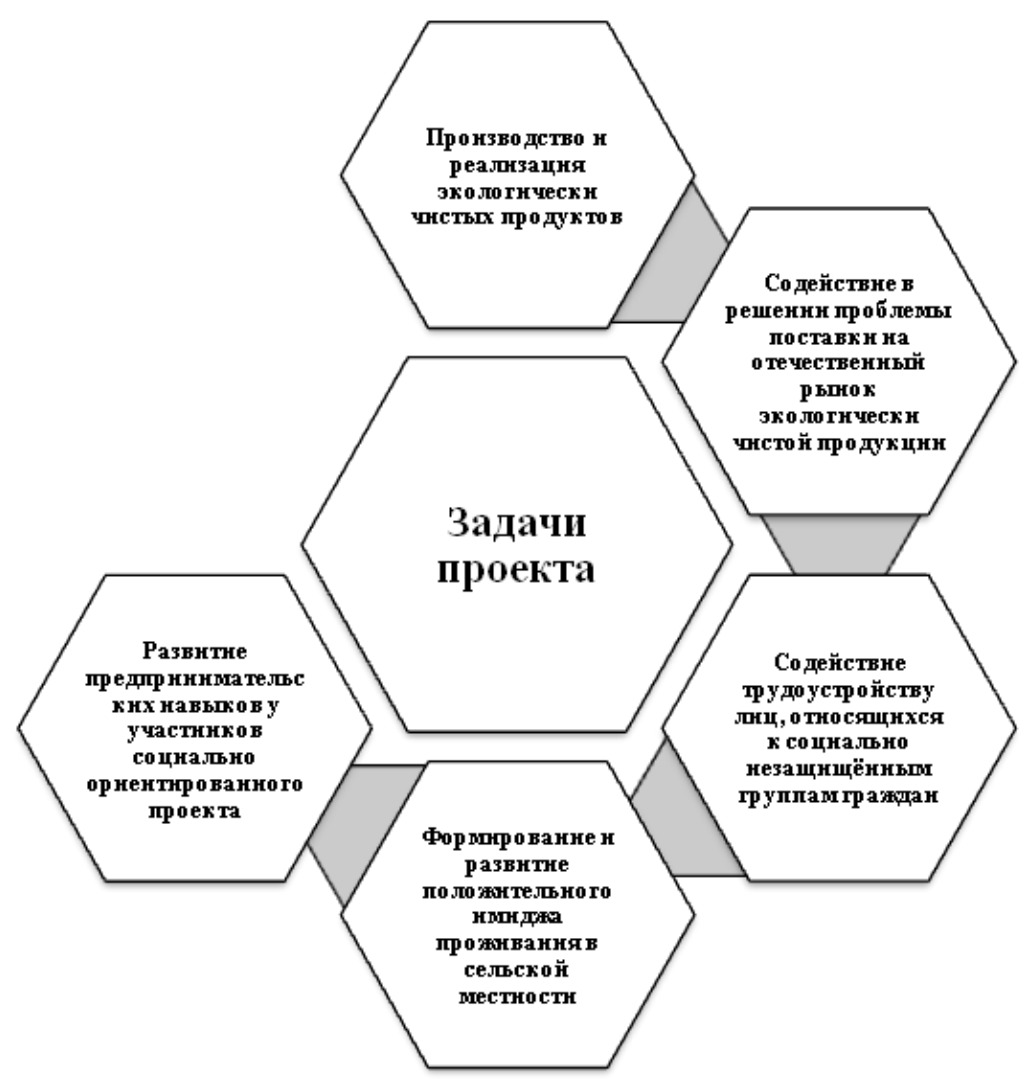

Рис. 9. Задачи проекта.

нес-планированию, правовым основам бизнеса, управлению командой и другие. Кроме того, они обучены находить источники финансирования проектов, знают о механизмах грунтового финансирования. Также студенты могут открыть свое дело, а бизнес-инкубатор поможет им в этом.

Таблица 1

Результаты реализации проекта студентов Среднерусского института управления - филиала РАНХиГС

\section{Экономический эффект проекта}

1. обеспечены заработком пенсионеры, их среднемесячный заработок составляет 11335 руб. в месяц;

2. Доход проекта в течение 6 месяцев составил более 260 тыс. рублей;

3. Жители деревни Морозово Покровского района Орловской области обучены навыкам ведения бизнеса;

4. Удалось обеспечить планируемый уровень продаж и рентабельность проекта (0,9\%).

В первую очередь, ведутся работы над созданием программы обучения основам бизнес-проектирования, включающую в себя лекционные курсы, мастер-классы и другие формы занятий. Обязательной практикой для обучающихся является самостоятельная разработка бизнес-плана социального или предпринимательского проекта и его публичная защита. По завершению обучения кто-то из студентов открывает свой бизнес на основе разработанного бизнес-плана или реализует социальный проект. На платформе инкубатора проектов в перспективе можно оказывать помощь внешним клиентам для развития их предпринимательских навыков, например, за счет проведения бизнес-тренингов, а также проведения тематических форумов.

Идеи проектов генерирует руководитель и председатель инкубатора проектов, а также студенты в ходе коллективного обсуждения. Тезисы проектов формируются в зависимости от ближайших конкурсов. Проводят экспертизу и отбор студенческих проектов руководитель инкубатора и его наставники, специализирующиеся на конкретных вопросах. Управление финансами, маркетингом и сбытом проектов осуществляется на базе инкубатора в рамках услуг инкубационного периода.

Взаимодействие с бизнес и инвест-сообществом происходит на основе обоюдных встреч и конкурсов, на базе ВУЗов на конференциях и форумах, за счет посещения 
студентами предприятия, а также доведения удачных проектов до стадии малых инновационных предприятий и трудоустройства студентов.

Участниками инкубатора проектов могут быть студенты 3-4 курса, 5 курса специалитета, магистры и аспиранты любых направлений подготовки ВУЗов.

Рекомендуется дальнейшее развитие программы подготовки студентов, наращивание партнерских отношений с предприятиями, а также решение вопроса мотивации студентов и преподавателей, участвующих в создании проектов. Но самое главное - это решение вопроса перехода бизнес-инкубатора на работу с внешними клиентами, что позволит инкубатору зарабатывать на платных услугах, а не только за счет реализации проектов и оказания услуг резидентам.

Инкубатор проектов контролирует функционирование проектов в учебных учреждениях, повышает имидж института, укрепляет партнерские отношения между руководством коммерческих организаций и образовательными организациями ВПО и ВО, способствует трудоустройству практикоориентированных студентов и абитуриентов, ориентирует социально-экономическую направленность результатов деятельности бизнес-инкубаторов, которые должны отвечать интересам региона, в котором они находятся. А также инкубатор проектов формирует предпринимательскую среду, способствующую созданию новых конкурентоспособных предприятий, профессиональному развитию студентов, аспирантов и целевой подготовке специалистов для предприятий региона.

Прибыль от деятельности бизнес-инкубаторов, функционирующих на базе инкубатора проектов, рассчитывается по формуле:

$$
\mathbf{P}=\mathbf{A} \times \%
$$

где:

P - доход от коммерциализации проекта

A - размер привлеченных инвестиций

\% - процент дохода от привлеченных денежных средств

Рассмотрим конкретный пример. Допустим, на базе Среднерусского института управления - филиала РАНХиГС действует инкубатор проектов. За первый год деятельности инкубатора удалось коммерциализировать два проекта, авторами которых стали студенты и преподаватели учреждения. Доход от привлеченных денежных средств оказался равным 5\%. Примерный размер привлеченных инвестиций - два миллиона рублей. Прибыть от коммерциализации проекта - 100 тысяч рублей.

Во втором году на фоне коммерциализации и массо- вой огласки реализуемых проектов, инкубатор открывает двери для внешних клиентов, предоставляя им платные услуги по продвижению проекта, а также оказывая помощь двум резидентам. Таким образом, инкубатор продолжает работать над предыдущими проектами и спонсирует новые.

В итоге, ориентировочно, доход от 4-ех реализованных проектов составит 200 тысяч рублей (табл. 2).

Оказание платных услуг внешним клиентам и резидентам инкубатора, при условии 1 часа бизнес-помощи в размере 300 рублей в час, или же оказание помощи при составлении и сводке бухгалтерского баланса, ведение аудита, позволит получить дополнительную прибыль не менее 100 тысяч рублей.

Таким образом, функционирование на базе Среднерусского института управления - филиала РАНХиГС инкубатора проектов, позволило бы получить учреждению дополнительный доход. В течение двух лет размер прибыли может составить 300 тысяч рублей.

Каждый из рассмотренных в статье способов процесса «выращивания» бизнеса по-своему результативен. Каждый из них развивает предпринимательскую культуру и коммерческую инфраструктуру университета, каждый направлен на развитие предпринимательских способностей абитуриентов высших и профессиональных учреждений.

Таблица 2

Прямая зависимость доходов от количества реализуемых проектов в инкубаторе

\begin{tabular}{|c|c|c|}
\hline $\begin{array}{c}\text { Количество реализуе- } \\
\text { мых проектов }\end{array}$ & Размер инвестиций & $\begin{array}{c}\text { Доход от коммерциа- } \\
\text { лизации проекта }\end{array}$ \\
\hline 2 & 2000000 & 100000 \\
\hline 4 & 4000000 & 200000 \\
\hline
\end{tabular}

Применение этих способов на практике, обеспечит ВУЗу высокий рейтинг, «создаст прозрачную инновационную среду внутри университета, для выстраивания перспективных партнерских отношений с внешними заказчиками инновационных научных разработок, сформирует кадровую базу обучающихся-специалистов в области малого бизнеса».

Стимулирование предпринимательской активности академической среды позволит университетам эффективно реализовывать свою третью миссию - миссию предпринимательского университета, обеспечит повышение уровня инновационного потенциала регионов, а также станет перспективным шагом на пути к реальному формированию национальной инновационной системы развития всего народного хозяйства страны 


\section{ЛИТЕРАТУРА}

1. Алексина И.С. Развитие малого предпринимательства в сфере сервиса с помощью создания эффективных бизнес-систем / И.С. Алексина // Экономика Размещение производственных сил и региональная экономика. - 2014. - № 1. - С. 16 - 26.

2. Артемова Д.И. Функционирование бизнес-инкубаторов при университетах Европы, Северной Америки и Азии / Д.И. Артемова, А.С. Малахова, Н.А. Мокринская, А.В. Мухачева, Ю.В. Рыбакова // Инновации. - 2016. - № 7 (213). - С. 75 - 86.

3. Балмасова Т.А. «Третья миссия» университета - новый проект развития? / Т.А. Балмасова //Высшее образование в России. - 2016. - № 8-9 (189). - С. 48 52.

4. Бизнес-инкубатор/Студенческая жизнь/ Студент/ Главная страница РАНХиГС [Электронный ресурс]. - Режим доступа: https://www.ranepa.ru/kto-ya-2/ student-bakalavriata/studencheskaya-zhizn-v-akademii/biznes-inkubator

5. Буняк Н.М. Предпринимательский университет: сущность и особенности формирования / Н.М. Буняк //Juvenis Scientia. - 2016. - № 2 (177). - С. 144 - 147.

6. Вовлеченность населения в малый бизнес в регионах РФ - Рейтинг 2019 [Электронный ресурс]. - Режим доступа: https://riarating.ru/ infografika/20190409/630122818.html

7. Выбираем ВУЗ: 25 лучших университетов Европы [Электронный ресурс]. - Режим доступа: https://ifehacker.ru/25-universitetov-evropy/

8. Гадиева И.А. Социально ориентированная проектная деятельность: практики и кейсы: сборник методических материалов / И.А. Гадиева / Москва: ФГБоу ВО РАНХиГС, 2019. - 152 с.

9. Захаров А.А. Стратегия «выращивания» бизнеса в университетской среде [Электронный ресурс] / А.А. Захаров. - Режим доступа: http://confer.mephi.ru/ archive/Lomonosov_2012/1949/30845_73a5.pdf

10. Институт экономики роста /РБК [Электронный ресурс]. - Режим доступа: https://www.rbc.ru/economics/05/02/2019/5c5948c59a794758389cfdf7

11. Как вырастить свое дело в тепличных условияхбсписок бизнес-инкубаторов в России [Электронный ресурс]. - Режим доступа: https://viafuture.ru/ privlechenie-investitsij/biznes-inkubatory-v-rossii\#vidy-biznes-inkubatorov-2-3-4

12. Коробов С.А. Предпринимательские навыки как основа развития инновационной среды / С.А.Коробов, В.О. Мосейко, Е.Ю. Марусинина, В.С. Епинина // Бизнес. Образование. Право. - 2019. - № 1 (46). - С. 59-63. DOI: 10.25683/VOLBI.2019.46.119.

13. Марусинина Е.Ю. Стратегическое значение инновационного потенциала экономической системы региона / Е.Ю. Марусинина, В.О. Мосейко, В.С. Епинина, С.А. Коробов // Региональная экономика. Юг России. - 2019. - № 2. - С. 102 - 113. D0I: 10.15688/re.volsu.2019.2.11

14. Пять лучших Российских бизнес инкубаторов [Электронный ресурс]. - Режим доступа: https://www.forbes.ru/svoi-biznes/startapy/59358-pyat-luchshihrossiiskih-biznes-inkubatorov

15. Распоряжению Правительства РФ от 2 июня 2016 года № 1083 - р «Стратегия развития малого и среднего предпринимательства в Российской Федерации на период до 2030 года» [Электронный ресурс]. - Режим доступа: http://static.government.ru/media/files/jFDd9wbAbApxgEiHNaXHveytq7hfP096.pdf

16. Рогова Е.М. Бизнес-инкубаторы как элементы системы технологического трансфера российских университетов / Е.М. Рогова //Инновации. - 2014. - № 7 (189). - C. $53-58$.

17. Социально-ориентированная проектная деятельность: практики и кейсы. Сборник методических материалов. Выпуск 2: [электрон. сборник. метод. мат. и статей] - Москва: ФГБОУ ВО РАНХиГС, 2017. -112 с.

18. Стратегия «Выращивание» бизнеса [Электронный ресурс]. - Режим доступа: http://confer.mephi.ru/archive/Lomonosov_2012/1949/30845_73a5.pdf

19. Причина не реализации основных целей и задач, Содержащихся в стратегии 2020 [сайт]. URLhttps://studbooks.net/2427003/pravo/prichina_realizatsii_ osnovnyh_tseley_zadach_soderzhaschihsya_strategii_2020 (дата обращения: 24.01.2020).- Текст.: электронный

(с) Григоренко Дарья Константиновна (ostroukhova1995@mail.ru).

Журнал «Современная наука: актуальные проблемы теории и практики» 